\title{
The Acidic Amino-acid Permease of Aspergillus nidulans
}

\author{
By J. H. ROBINSON,* C. ANTHONY AND W. T. DRABBLE, \\ Department of Physiology and Biochemistry, University of Southampton, \\ Southampton $\mathrm{SO}_{9}{ }_{5} \mathrm{NH}$
}

(Received 3 January 1973; revised 9 May 1973)

\begin{abstract}
SUMMAR Y
A single permease is responsible for the active transport of L-glutamate, L-aspartate and L-cysteate in Aspergillus nidulans. Apparent $K_{m}$ values are I $80 \mu \mathrm{M}$, I $00 \mu \mathrm{M}$ and $\mathrm{I} 90 \mu \mathrm{M}$ respectively. The transport of glutamate occurs against a concentration gradient of at least $\mathrm{I}: 200$, is inhibited by azide and cyanide, and shows a $\mathrm{pH}$ optimum of 5.0 and a temperature optimum of $45^{\circ} \mathrm{C}$.
\end{abstract}

\section{INTRODUCTION}

Several amino-acid permeases have been characterized in bacteria and fungi. The aminoacid permeases of bacteria are fairly specific: a given permease binds and transports only a few structurally related amino acids. By contrast, the amino-acid permeases of fungi tend to resemble the transport systems of animal cells in having a wider specificity (Robinson, I973).

Acidic amino-acid permeases of the filamentous fungi Penicillium chrysogenum (Hunter \& Segel, 1971) and Neurospora crassa (Pall, 1970) have been described. The present paper describes the acidic amino-acid permease of Aspergillus nidulans. A preliminary report of some of these results has been published (Robinson, Anthony \& Drabble, 197I).

\section{METHODS}

Chemicals. All chemicals were reagent grade and almost all were obtained from British Drug Houses Ltd, Poole, Dorset. The exceptions were: butyl-PBD [2-(4-tert-butylphenyl)5-(4-biphenylyl)-I, 3, 4-oxadiazole] from Koch Light Laboratories Ltd, Colnbrook, Buckinghamshire; malt extract (L 39) and agar no. 3 (L 13) from Oxoid Ltd, London; L-[U- $\left.{ }^{14} \mathrm{C}\right]$ aspartate $(227 \mathrm{mCi} / \mathrm{mmol}), \mathrm{L}-\left[\mathrm{U}-{ }^{14} \mathrm{C}\right]$ glutamate $(14.7 \mathrm{mCi} / \mathrm{mmol})$ and L- $\left[{ }^{35} \mathrm{~S}\right] \mathrm{cystine}$ $(83 \mathrm{mCi} / \mathrm{mmol})$ from the Radiochemical Centre, Amersham, Buckinghamshire; 3-acetylpyridine $\mathrm{NAD}^{+}$, L-aspartate, D-glutamate, DL- $\alpha$-methylglutamate and L-glutamic dehydrogenase (type II) from Sigma Chemical Company Ltd, London.

Preparation and purification of $\left[{ }^{35}\right.$ S $]$ cysteic acid. $\left[{ }^{35} \mathrm{~S}\right] \mathrm{C}$ ysteic acid was prepared from $\left[{ }^{35} \mathrm{~S}\right]$ cystine by the performate oxidation method of Moore (1963).

Organism and growth media. A translocation-free, biotin-requiring strain (bi-1) (Pontecorvo, Roper, Hemmons, MacDonald \& Buften, 1953) of Aspergillus nidulans was used in this work, and was kindly supplied by Dr D. J. Cove, Department of Genetics, University of Cambridge. Stock cultures were maintained on slopes of malt extract $(3 \%, w / v)$ solidified with Oxoid agar no. $3(1.5 \%, \mathrm{w} / \mathrm{v})$.

The medium used for growth of liquid cultures contained (per litre): glucose, io $\mathrm{g}$; $\mathrm{KCl}, 0.5 \mathrm{~g} ; \mathrm{MgSO}_{4} .7 \mathrm{H}_{2} \mathrm{O}, 0.5 \mathrm{~g}$; $\mathrm{FeSO}_{4} .7 \mathrm{H}_{2} \mathrm{O}$, 0.1 mg; biotin, 0.0I $\mathrm{mg}$. The $\mathrm{pH}$ buffer in

* Present address: Department of Hormone Biochemistry, Imperial Cancer Research Fund, Lincolns' Inn Fields, London. 
the medium was $\mathrm{Na}_{2} \mathrm{HPO}_{4} / \mathrm{KH}_{2} \mathrm{PO}_{4}(\mathrm{pH} \mathrm{6} 5,0 \cdot \mathrm{I} \mathrm{M})$ and the concentration of nitrogen source was usually $25 \mathrm{~mm}$. The nitrogen source and phosphates were sterilized together; the glucose and salts (containing the biotin) were sterilized separately and added aseptically to the rest of the medium.

Preparation of standard suspensions of conidia. Stock cultures were grown on malt extractagar slopes at $37^{\circ} \mathrm{C}$ for about 5 days when dense conidiation was visible. The slopes were stored at $2{ }^{\circ} \mathrm{C}$ until required. Conidia from a stock slope were suspended in $10 \mathrm{ml}$ of sterile saline $\left(\mathrm{NaCl}, 0.85 \%\right.$; Nonidet $\mathrm{P}_{40}$ wetting agent, 0. or $\%$ ) by rubbing the agar surface with the tip of a sterile pipette. This suspension of conidia was used to inoculate pearl barley. The pearl barley (approx. $30 \mathrm{~g}$ ) had previously been autoclaved in $500 \mathrm{ml}$ Erlenmeyer flasks at I2I ${ }^{\circ} \mathrm{C}$ for $2 \mathrm{~h}$, and moistened with Io $\mathrm{ml}$ of a sterile solution of glycerol $(3 \%, \mathrm{w} / \mathrm{v})$ and asparagine $(0 . \mathrm{I} \%)$. After inoculation, the flasks were incubated at $37^{\circ} \mathrm{C}$ until the barley surface was covered with conidia ( 2 to 3 days) and then stored at $2{ }^{\circ} \mathrm{C}$ for up to 3 days. The conidia were suspended by vigorous shaking with successive volumes (approx. $100 \mathrm{ml}$ ) of sterile saline and filtered through two layers of butter muslin plus two layers of cotton sheet (sterilized by autoclaving) to remove all fragments of broken conidiophores and hyphae. The conidia were aseptically harvested by centrifugation (I8000 $\mathrm{g}$ ) for $10 \mathrm{~min}$, washed and resuspended in sterile saline, shaken vigorously to break up chains of conidia and finally stored at $2{ }^{\circ} \mathrm{C}$. The conidial suspension was counted with a haemocytometer slide. A suspension usually contained $\mathrm{I}-2 \times 10^{8}$ conidia $/ \mathrm{ml}$.

Germination of conidia in aerated cultures. Conidia (approx. $10^{7} / \mathrm{ml}$ medium) were incubated in the medium described above at $30{ }^{\circ} \mathrm{C}$ in conical rimless flasks (with aluminium caps and with invaginations in the sides to increase aeration) on a gyrotary shaker (240 rev./min) (L. H. Engineering Co. Ltd, Stoke Poges, Buckinghamshire). Unless otherwise stated, the conidia were germinated until germ tubes were just visible in more than $80 \%$ of conidia (usually io to $\mathrm{I} 2 \mathrm{~h}$ after inoculation).

Measurement of amino-acid transport. Germinated conidia were filtered under vacuum through a $47 \mathrm{~mm}$ diameter Millipore filter (type HAWP, $0.45 \mu \mathrm{m}$ pores) and washed with $2 \times 100 \mathrm{ml}$ volumes of ice-cold distilled water. The germinated conidia were scraped off the Millipore filter and the bulk was kept at $2{ }^{\circ} \mathrm{C}$ in a glass Petri dish while portions were weighed, placed into sealed plastic vials and stored at $2{ }^{\circ} \mathrm{C}$ for up to $3 \mathrm{~h}$ until required for assay. Each weighed sample was added to $I \cdot 5 \mathrm{ml}(4 / 3$ strength) nitrogen-free medium (at $30{ }^{\circ} \mathrm{C}$ ) in I IO $\mathrm{mm} \times \mathrm{I} 2 \mathrm{~mm}$ glass tubes with a small (IO $\mathrm{mm}$ long) polypropylene-coated stirring bar in each tube. The germinated conidia were stirred in the tubes, by means of a submersible magnetic stirrer, for approx. $90 \mathrm{~s}$ before addition of $0.5 \mathrm{ml}$ aqueous solution of a radioactive compound. Samples $(0.5 \mathrm{ml})$ were withdrawn at time intervals with a widebore I-ml pipette, filtered under suction through Whatman no. I paper discs (I $3 \mathrm{~mm}$ diameter) and washed with two Io-ml volumes of ice-cold, distilled water. The discs were sucked dry and placed in glass scintillation vials with ro $\mathrm{ml}$ scintillation fluid $(8 \mathrm{~g}$ butylPBD dissolved in toluene:methanol, 3:I). Samples were counted for two 5-min periods in a Beckman CPM 200 scintillation counter. Under the conditions used, quenching of the radioactivity was approximately the same in every sample, and in no case did it exceed $10 \%$ of the total radioactivity. A large sample of the germinated conidia was weighed and dried to constant weight at $105{ }^{\circ} \mathrm{C}$. From the wet-weight to dry-weight ratio of this sample, the dry weights of the samples used in the assays were calculated. The amount of substrate transported by the conidia during the first $3 \mathrm{~min}$ of assay was calculated from the total radioactivity associated with the germinated conidia and the known specific activity of the radioactive substrate. 
Extraction of intracellular amino acids. Germinated conidia were harvested by filtration, washed with distilled water $\left(2{ }^{\circ} \mathrm{C}\right)$ and weighed samples stored at $2{ }^{\circ} \mathrm{C}$ until required (as described above). The germinated conidia were extracted in boiling distilled water for $20 \mathrm{~min}$ (approx. $2 \mathrm{mg}$ dry wt germinated conidia/ml water). The residue was sedimented by centrifugation and the supernatant liquid (referred to as 'the extract') collected.

Determination of glutamate in extracts. Glutamate was assayed enzymatically using L-glutamic dehydrogenase and the $\mathrm{NAD}^{+}$analogue 3-acetylpyridine $\mathrm{NAD}^{+}$(Kaplan, Ciotti \& Stolzenbach, 1956). The reaction mixture contained 5 to $30 \mathrm{nmol}$ glutamic acid, $600 \mathrm{nmol} 3$-acetylpyridine $\mathrm{NAD}^{+}, 25 \mu$ mol-tris-HCl buffer $(\mathrm{pH} 8 \cdot 0$ ) and approx. 5 units of glutamic dehydrogenase (added to start the reaction) in a total volume of $0.5 \mathrm{ml}$. After $30 \mathrm{~min}$, when the reaction had gone to completion, the extinction at $363 \mathrm{~nm}$ was measured with tris- $\mathrm{HCl}$ buffer in the reference cell (Pye-Unicam SP500 spectrophotometer). The extinction was related to the concentration of glutamate by means of a standard curve.

Chromatography of extracts. Boiling-water extracts of radioactive germinated conidia were evaporated to dryness at $30{ }^{\circ} \mathrm{C}$ by rotary evaporation under reduced pressure from a water-flow pump. The radioactive residue ( $1.064 \times 10^{6}$ d.p.m.) was dissolved in $0.2 \mathrm{ml}$ distilled water, and a suitable volume ( 10 or $50 \mu \mathrm{l}$ ) of this extract was spotted on to Whatman no. I chromatography paper $(23 \mathrm{~cm} \times 57 \mathrm{~cm})$. The chromatogram was run in water-saturated phenol containing $0.05 \%$ ammonia (sp. gr. 0.88 ) for $24 \mathrm{~h}$. The chromatogram was dried for a further $24 \mathrm{~h}$ in an air stream, and then cut into longitudinal strips which were scanned for radioactivity using a Dünnschicht model II scanner. The radioactive spots were identified by the position of marker standards (stained with ninhydrin in $0.5 \%$ acetone), cut out, and the paper added to butyl-PBD scintillation fluid for determination of radioactivity.

Statistical methods. The statistics used for ' $P$ ' values were taken from Mather (I965).

\section{RESULTS}

Preliminary results showed that the rate of glutamate transport in conidia of Aspergillus nidulans was very low and that the highest specific activity of the glutamate transport system was measured just after the first observable emergence of germ tubes (this is discussed in detail by Robinson, Anthony \& Drabble, 1973). Conidia were therefore germinated to this stage of development for characterization of the glutamate transport system. It is likely that the metabolic characteristics of germinated conidia are essentially the same as those of fully developed mycelium and the use of such organisms facilitates greater reproducibility of experimental conditions.

The assay system for measurement of amino-acid transport. The time course of glutamate transport by germinated conidia of Aspergillus nidulans was approximately linear over the first three minutes of assay (Fig. I $a$ ). This initial three minute period was used to calculate initial rates of glutamate uptake in all subsequent experiments. Germinated conidia stored in the growth medium for $5 \mathrm{~h}$ at $2{ }^{\circ} \mathrm{C}$ transported glutamate at the same rate as germinated conidia which had been harvested immediately from the growth medium (Fig. I $a$ ).

The measured rate of transport of glutamate was directly proportional to the mass of germinated conidia in the assay system, in the range used in this work (Fig. I $b$ ).

The method of harvesting and washing had no effect on the capacity of the germinated conidia to transport glutamate. To show this, conidia were germinated with glycine (Io mM) as nitrogen source. This allowed full development of the permease (Robinson et al. 1973) and had little effect on the rate of glutamate transport (Table 2). Before measurement of glutamate transport the conidia were either harvested, washed and stored in the usual 

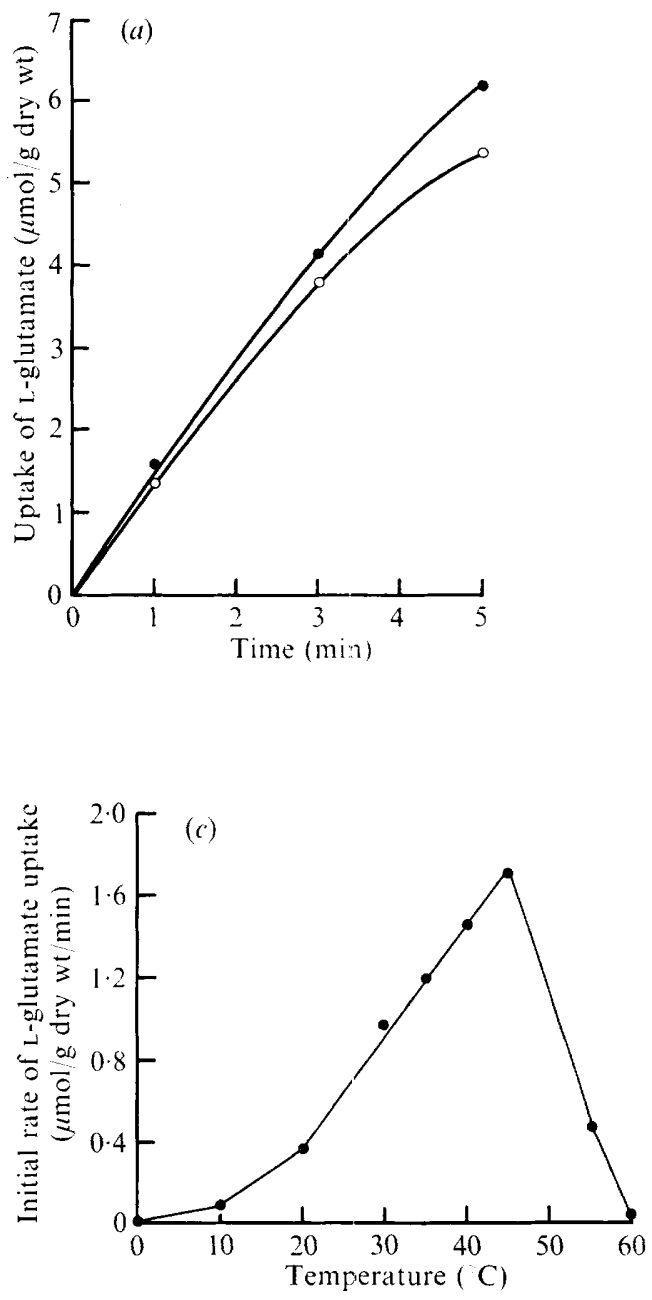
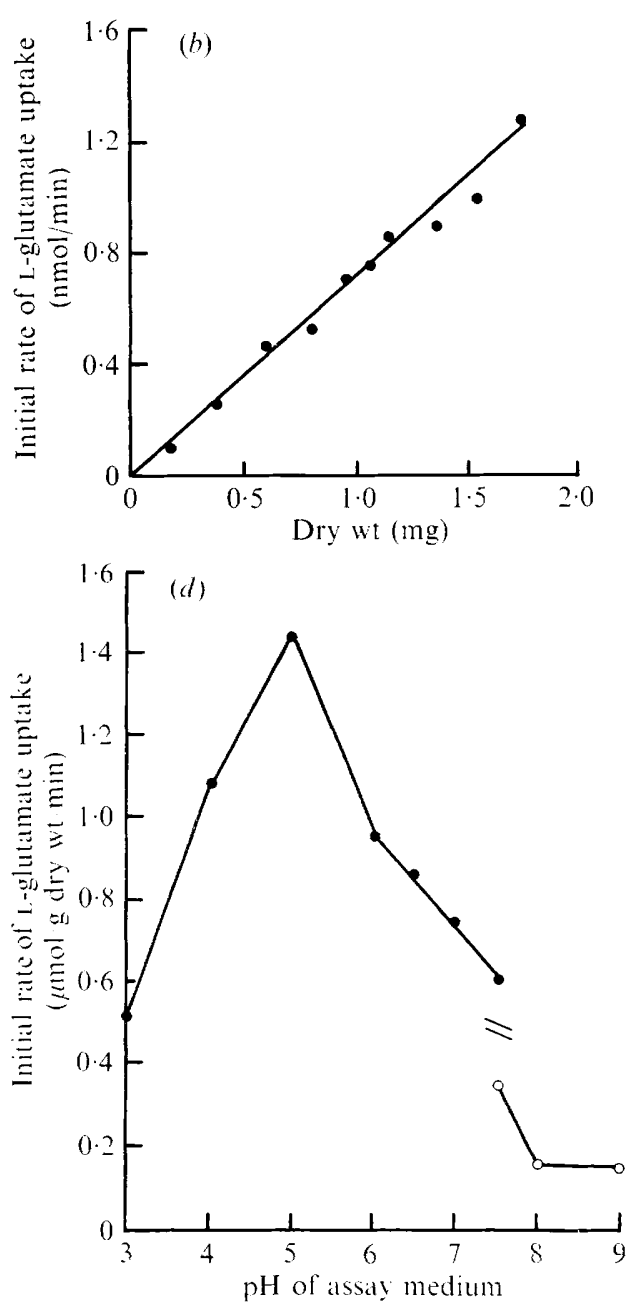

Fig. 1. The kinetics of glutamate uptake in germinated conidia of Aspergillus nidulans. Conidia were germinated for approx. $10 \mathrm{~h}$ in glutamate medium. Uptake of $\mathrm{L}-\left[\mathrm{U}-{ }^{14} \mathrm{C}\right]$ glutamate (0.1 $\mathrm{mm}$ ) by the germinated conidia (usually I mg dry wt) was as described in Methods. (a) Time course of glutamate uptake. (๑), Transport assayed immediately after harvesting; ( $O$ ), transport assayed after storage of the germinated conidia in the growth medium for $5 \mathrm{~h}$ at $4{ }^{\circ} \mathrm{C}$ and subsequent harvesting. (b) Rate of uptake of glutamate as a function of mass of germinated conidia. (c) Rate of glutamate uptake as a function of temperature. $(d)$ Rate of glutamate uptake as a function of the $\mathrm{pH}$ value of the uptake medium. The $\mathrm{Na} / \mathrm{K}$ phosphate buffer in the transport assay medium was replaced with a mixture of $\mathrm{KCl}(\mathrm{O} \cdot \mathrm{I} \mathrm{M})$ and $\mathrm{NaCl}(\mathrm{O} \cdot \mathrm{I} \mathrm{M})$ and either (-), citric-acid/orthophosphoricacid buffer (0.02 M) or (O), tris-HCl buffer (0.02 M).

manner (see Methods) or were kept at $30{ }^{\circ} \mathrm{C}$ in the glycine growth medium; for assay of transport in this circumstance the $\left[{ }^{14} \mathrm{C}\right]$ glutamate $\left(O^{\circ} \mathrm{I} \mathrm{mM}\right)$ was added directly to the glycine medium. It was found that the initial rate of transport of glutamate by washed germinated conidia $(0.90 \mu \mathrm{mol} / \mathrm{g}$ dry $\mathrm{wt} / \mathrm{min})$ was the same as that measured in unwashed germinated conidia $(0.87 \mu \mathrm{mol} / \mathrm{g}$ dry $\mathrm{wt} / \mathrm{min})$.

The method of measuring uptake of compounds includes washing the radioactive germinated conidia (on a filter) with ice-cold distilled water to remove extracellular radio- 


\section{Table I. Intracellular concentration of glutamate in germinated conidia}

Conidia were germinated for $12 \mathrm{~h}$ in medium containing glutamate as nitrogen source. Some germinated conidia were used for measurement of glutamate transport (see Methods); the remainder were extracted for $20 \mathrm{~min}$ with boiling water and the concentration of glutamate in the extract determined by the glutamic dehydrogenase assay (for experimental details see Methods).

Initial concentration of glutamate in medium (mм) Final concentration of glutamate in medium (mM)

Intracellular concentration of glutamate in germinated conidia (nmol/mg dry wt)

Dry wt $(\mathrm{mg} / \mathrm{ml})$ of germinated conidia at $\mathrm{I} 2 \mathrm{~h}$

Rate of L-glutamate transport $(\mu \mathrm{mol} / \mathrm{g}$ dry wt $/ \mathrm{min})$

$\begin{array}{cc}\text { Flask I } & \text { Flask 2 } \\ 2.5 & 25 \\ 1 \cdot 7 & \text { not done } \\ 64.3(21.4 \mathrm{~mm}) * & 68.4(22.8 \mathrm{mM})^{*} \\ & \\ 0.16 & 0.22 \\ 1.30+ & 1 \cdot 80\end{array}$

* A weight of water equivalent to three times the dry weight of the organism was assumed (Pall, 1970).

$\uparrow$ This lower rate of transport is attributable to the slower development of these conidia (on $2.5 \mathrm{~mm}$ glutamate).

active substrate (see Methods). The measured rate of glutamate uptake was the same whether germinated conidia were washed or not, indicating that the washing procedure did not remove intracellular radioactive compounds from the free pool (C. Anthony and R. J. Cook, unpublished).

A possible criticism of the assay method for glutamate uptake is that the initial rate of $\left[{ }^{14} \mathrm{C}\right]$ glutamate uptake, measured over the first three minutes, might be artificially high as a result of rapid binding of glutamate to the membrane. To discount this possibility it was necessary to measure uptake of $\left[{ }^{14} \mathrm{C}\right]$ glutamate after a preliminary period of 'equilibration' of the germinated conidia in a non-radioactive glutamate medium. Germinated conidia were aerated in medium containing non-radioactive glutamate $(0 \cdot \mathrm{I} \mathrm{mm})$ for $20 \mathrm{~min} .\left[{ }^{14} \mathrm{C}\right]$ glutamate was then added in sufficient quantity to restore the medium glutamate concentration to approximately $0.1 \mathrm{~mm}$. The initial rate of glutamate uptake by germinated conidia, preincubated with $0.1 \mathrm{~mm}$-glutamate, was $\mathrm{I} \cdot 70 \mu \mathrm{mol} / \mathrm{g} \mathrm{dry} \mathrm{wt} / \mathrm{min}$ and the initial rate, without pre-incubation, was $\mathrm{I} \cdot 84 \mu \mathrm{mol} / \mathrm{g}$ dry $\mathrm{wt} / \mathrm{min}$. The similarity of the two values indicates that the assay method measures the activity of the glutamate permease, rather than an initial binding phenomenon.

Transport of glutamate against a concentration gradient. When conidia were germinated in a medium initially containing $2.5 \mathrm{~mm}$-glutamate (final concentration in medium after germination, $\mathrm{I} \cdot 7 \mathrm{~mm}$ ), the intracellular concentration of glutamate was $2 \mathrm{I} \mathrm{mM}$ (Table $\mathrm{I}$ ). This demonstrates that glutamate was taken up against a concentration gradient ( $1: 13)$ during the germination process. After germination with $25 \mathrm{~mm}$-glutamate the concentration in the glutamate pool was $22.8 \mathrm{~mm}$. In most of the work described in this paper conidia were germinated in $25 \mathrm{~mm}$-glutamate before measurement of transport of $\left[{ }^{14} \mathrm{C}\right]$ glutamate $(0 \cdot \mathrm{I} \mathrm{mM})$. Thus the transport of glutamate as usually measured (in this work) occurs against a concentration gradient of $\mathrm{I}: 228$.

Metabolism of $\left[{ }^{14} \mathrm{C}\right]$ glutamate during the transport assay period. The distribution of intracellular radioactivity after $3 \mathrm{~min}$ uptake of $\left[{ }^{14} \mathrm{C}\right]$ glutamate by germinated conidia was determined. The transport was measured with $0 \cdot 1 \mathrm{mM}-\left[\mathrm{U}-{ }^{14} \mathrm{C}\right] \mathrm{glutamate}(0.03 \mu \mathrm{Ci} / \mathrm{nmol})$. The germinated conidia were washed, extracted and chromatographed as described in Methods. More than $95 \%$ of the radioactivity was extracted from the germinated conidia into boiling water and $76 \%$ of this was recovered from the chromatograms. Of the extracted compounds $47 \%$ of the radioactivity was found in glutamate, $6 \%$ in aspartate, $8 \%$ in 
glutamine-plus-alanine and $\mathrm{I} 6 \%$ in other compounds. Thus at least $47 \%$ of the glutamate transported during the 3 -min assay period could be recovered as glutamate. However, some of the transported glutamate may have been metabolized to a product (such as glutamine) which was then degraded to glutamate during extraction and chromatography, and so the value for unchanged glutamate may be less than $47 \%$.

Radioactive $\mathrm{CO}_{2}$ produced by oxidation of transported $\left[{ }^{14} \mathrm{C}\right]$ glutamate is not measured in the transport assay system. For this reason all values for rate of transport of $\left[{ }^{14} \mathrm{C}\right]$ glutamate are underestimated by a proportion representing the glutamate oxidized during the 3-min assay period.

The $\mathrm{pH}$ and temperature optima for glutamate transport. The transport of glutamate by germinated conidia was measured at various temperatures and $\mathrm{pH}$ values. The results given in Fig. I $c$ show that the temperature optimum for glutamate transport by germinated conidia was $45^{\circ} \mathrm{C}$; this high temperature optimum is probably related to the high temperature optimum observed for growth of Aspergillus nidulans ( $40{ }^{\circ} \mathrm{C}$ ) (Pontecorvo et al. 1953). The high $Q_{10}$ value measured here $(2 \cdot 45)$ for the increasing rate of glutamate transport between 20 and $45^{\circ} \mathrm{C}$ is characteristic of biological processes but is not readily reconciled with diffusion being the sole mediating process for glutamate transport.

The rate of glutamate transport varied with the $\mathrm{pH}$ value of the assay medium as shown in Fig. I $d$; there was a $\mathrm{pH}$ optimum at $\mathrm{pH} 5^{\circ}$. At this $\mathrm{pH}$ value most of the glutamate in the assay medium was present in the anionic form; a small proportion was present in the protonated form. The $\alpha$-carboxyl group was entirely in the non-protonated form owing to its lower $\mathrm{p} K_{a}$ value ( $\mathrm{p} K_{a}$ values; $\alpha$-carboxyl, $2 \cdot 19 ; \gamma$-carboxyl, $4.25 ; \alpha$-amino, 9.67). Transport of glutamate was generally measured at $\mathrm{pH} \mathrm{6.5.} \mathrm{At} \mathrm{this} \mathrm{pH}$ value, a very small proportion of glutamate existed in the protonated form and thus only a very small proportion was available for transport by neutral and general amino-acid permeases.

Inhibition of glutamate transport by cyanide, azide and valinomycin. Transport of glutamate ( $O$. I $\mathrm{mM}$ ) by germinated conidia was almost completely prevented by inhibitors of energyyielding reactions. After pre-incubation of germinated conidia for Io min with sodium azide (I $\mathrm{mm}$ ) or sodium cyanide ( $5 \mathrm{~mm}$ ) the initial rate of glutamate transport was inhibited by $95 \%$ and $86 \%$, respectively. Both azide and cyanide inhibit electron transport in mitochondria. Thus, the transport of glutamate $(0 \cdot \mathrm{I} \mathrm{mm})$ by germinated conidia appears to be energy-dependent. This energy can probably be supplied by endogenous sources because the uptake rate was not diminished by omitting glucose from the assay system. Bubbling of nitrogen through the uptake medium (for $15 \mathrm{~min}$ before addition of glutamate) reduced the transport rate by $90 \%$, thus indicating that the energy-yielding system was essentially aerobic (C. Anthony and R. J. Cook, unpublished).

Valinomycin, an antibiotic and antifungal agent produced by Streptomyces spp., also inhibited glutamate transport. Two minutes after incubation of germinated conidia with I $\mu \mathrm{g}$ valinomycin $/ \mathrm{ml}$ (approx. I $\mu \mathrm{M}$ ), the rate of glutamate transport was inhibited by $95 \%$. Valinomycin uncouples oxidative phosphorylation by increasing permeability of the mitochondrial membrane to potassium ions (Hunter \& Schwartz, 1967). Its antibacterial action results from a similar increase in permeability of the bacterial cell membrane to potassium ions. This leads to inhibition of glutamate transport in some bacteria (Gale, I971). Thus, valinomycin may have inhibited glutamate transport into Aspergillus nidulans either by restricting the energy supply needed for active transport of glutamate or by inhibiting a glutamate-dependent flux of potassium ions across the cell membrane.

Kinetics of L-glutamate transport. The variation of the initial rate $(V)$ of glutamate transport with the concentration of glutamate $(S)$ in the assay medium is shown in Fig. $2 a$. The 

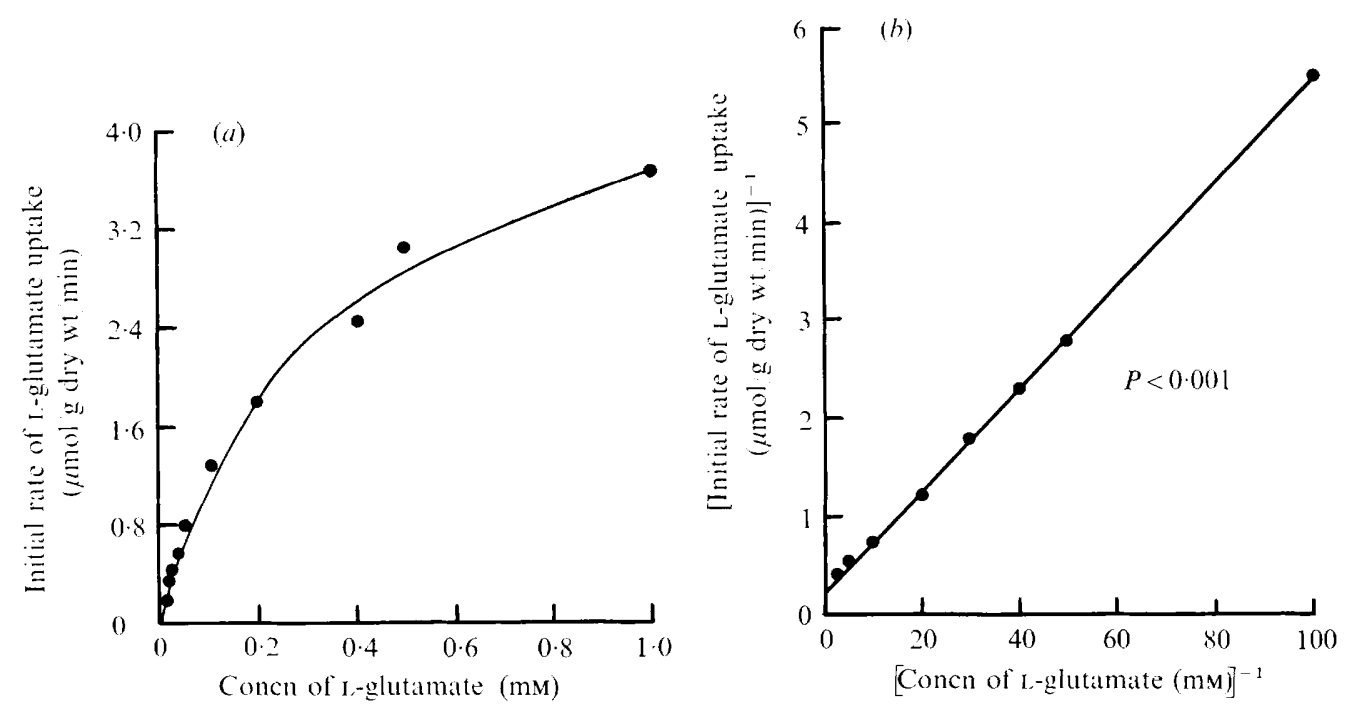

Fig. 2. Kinetics of glutamate transport by germinated conidia of Aspergillus nidulans. (a) Transport of $\mathrm{L}-\left[\mathrm{U}-{ }^{14} \mathrm{C}\right]$ glutamate as measured with various concentrations of $\mathrm{L}$-glutamate in the assay medium. Experimental details were as given for Fig. I. (b) Double-reciprocal plot of the same kinetic data.

double-reciprocal, Lineweaver-Burk plot of the results (Fig. $2 b$ ) shows that only one glutamate transport system was operating over the range $10 \mu \mathrm{M}$ to $500 \mu \mathrm{M}$. The apparent $K_{m}$ value was o. I $8 \mathrm{~mm}$ and the $V_{\text {max. }} 4.35 \mu \mathrm{mol} / \mathrm{g}$ dry wt $/ \mathrm{min}$.

Specificity of the glutamate transport system. The inhibitory effects of various amino acids and related compounds are shown in Table 2. At the lower concentration (I mM) only L-aspartate and L-cysteate inhibited glutamate transport by more than $50 \%$. L-Histidine, L-phenylalanine and L-asparagine inhibited transport by more than $25 \%$. All other compounds tested (at I mM) inhibited transport by less than $25 \%$. It can be concluded that an $\alpha$-hydrogen atom and an $\alpha$-amino group are probably necessary for binding to the glutamate permease because DL- $\alpha$-methylglutamate and N-acetyl-L-glutamate did not inhibit, even at Io mM. It is possible that some amino acids inhibit glutamate transport by competing for the supply of energy available to the glutamate permease. This would occur if the same energy system is used by the glutamate permease and by other amino-acid permeases.

L-Aspartate, L-cysteate, L-asparagine, L-histidine and L-phenylalanine (all I mM) inhibited glutamate (O.I $\mathrm{mM}$ ) uptake by more than $25 \%$ (Table 2 ). The type of inhibition was investigated by measuring the kinetics of glutamate transport with the inhibiting compound in the assay medium. A Ioo-fold excess of unlabelled L-lysine was added to the assay medium to prevent any possible transport of glutamate by a general (non-specific) aminoacid permease.

In the presence of L-aspartate or L-cysteate, the $K_{m}$ for glutamate transport by Aspergillus nidulans changed but the $V_{\text {max. }}$ remained constant (Fig. 3). These amino acids were therefore competitive inhibitors and they were probably transported by the same permease as glutamate. L-Histidine, L-phenylalanine and L-asparagine were non-competitive inhibitors (Fig. 4); it is therefore unlikely that the latter three amino acids bound to the initial binding site of the glutamate permease. 
Table 2. Inhibition of glutamate uptake by amino acids and related compounds

Germinated conidia were stirred in the assay medium with the potential inhibitor (either $\mathbf{~ m M ~ o r ~}$ IO $\mathrm{mM}$ ) for approx. $90 \mathrm{~s}$ before addition of $\left[{ }^{14} \mathrm{C}\right]$ glutamate $(0.1 \mathrm{~mm})$. The initial rate of glutamate uptake was measured during the first $3 \mathrm{~min}$ of assay as described in Methods. Results are expressed as $\%$ inhibition determined by comparing the inhibited rate of glutamate transport with the rate measured in the absence of inhibitor.

\begin{tabular}{|c|c|c|c|c|c|}
\hline \multirow[b]{2}{*}{ Inhibitor } & \multicolumn{2}{|c|}{ Inhibition $(\%)$} & \multirow[b]{2}{*}{ Inhibitor } & \multicolumn{2}{|c|}{ Inhibition $(\%)$} \\
\hline & I $\mathrm{mm}$ & $10 \mathrm{~mm}$ & & I $\mathrm{mM}$ & Io $\mathrm{mm}$ \\
\hline & & & Ammonia & 3 & 9 \\
\hline L-Aspartate & 80 & 89 & L-Alanine & 12 & 49 \\
\hline L-Cysteate & 75 & 83 & L-Cysteine & I7 & 46 \\
\hline & & & Glycine & - & 8 \\
\hline L- $\alpha$-Aminoadipate & 22 & 72 & L-Isoleucine & I5 & 12 \\
\hline DL- $\alpha$-Aminobutyrate & 20 & 34 & L-Methionine & 16 & 50 \\
\hline D-Glutamate & 22 & 43 & L-Proline & 0 & 2 \\
\hline DL- $\alpha$-Methylglutamate & - & 0 & L-Serine & 0 & I 5 \\
\hline N-Acetyl-L-glutamate & - & 0 & L-Threonine & 6 & 24 \\
\hline L-Asparagine & 34 & 62 & L-Tyrosine & 6 & 29 \\
\hline L-Glutamine & I8 & 52 & L-Valine & 8 & 19 \\
\hline & & & L-Histidine & 49 & 86 \\
\hline L-Lysine & 一 & 0 & L-Phenylalanine & 27 & 75 \\
\hline L-Arginine & - & 0 & L-Tryptophan & 24 & 75 \\
\hline
\end{tabular}

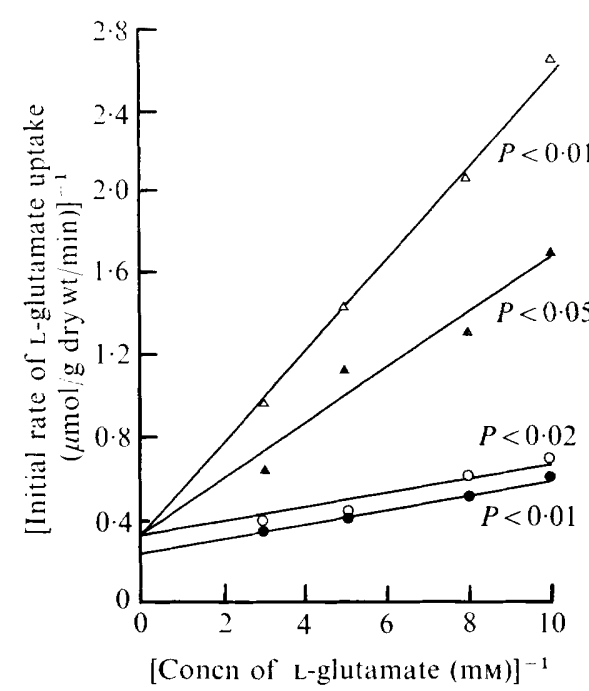

Fig. 3. Competitive inhibition of L-glutamate transport by L-aspartate and by L-cysteate. Transport of glutamate was measured in the presence of other amino acids. L-Lysine (IO mM) was included in each assay to inhibit transport of glutamate by a general amino acid permease. Experimental details were as given for Fig. I. Glutamate only, ; glutamate with lysine, $O$; glutamate with lysine and aspartate $(0.25 \mathrm{~mm}), \boldsymbol{\Delta} ;$ glutamate with lysine and cysteate (I mM), $\triangle$.

Transport of $\mathrm{L}$-aspartate and $\mathrm{L}$-cysteate. The results above indicate that $\mathrm{L}$-aspartate and L-cysteate may be transported by the same permease as L-glutamate. Measurements of the kinetics of transport of L-aspartate and L-cysteate by germinated conidia of Aspergillus nidulans supported this conclusion. The kinetics of $\mathrm{L}-\left[{ }^{14} \mathrm{C}\right]$ aspartate transport in the presence or in the absence of L-glutamate $(0.5 \mathrm{~mm})$ show that glutamate was a competitive inhibitor of aspartate transport (Fig. 5a). The kinetics of transport of $\left[{ }^{35}\right.$ S $]$ cysteate are shown in 


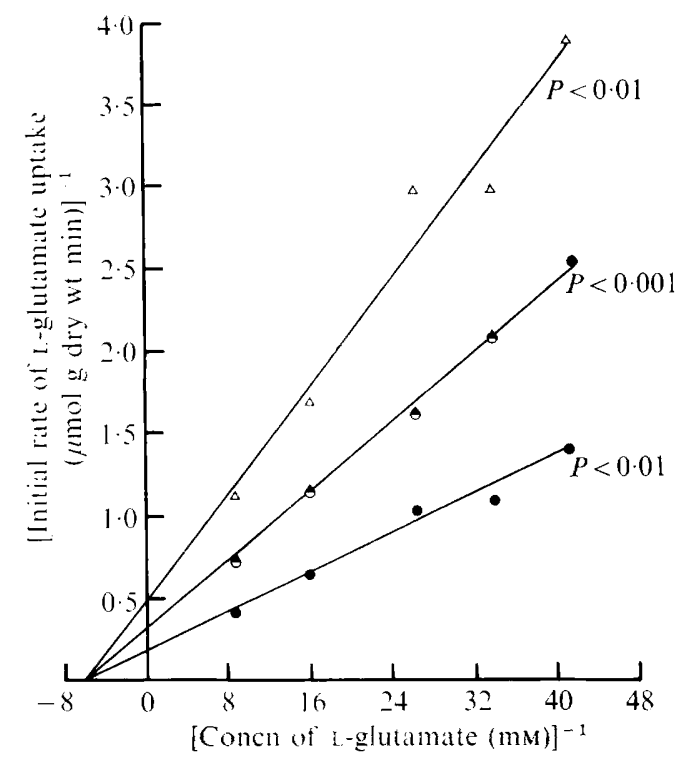

Fig. 4. Non-competitive inhibition of L-glutamate transport by L-histidine, L-phenylalanine and L-asparagine. Experimental details were as given for Fig. 3 except that L-lysine was not included in the assay medium. Glutamate only, ; glutamate with phenylalanine ( $\mathrm{mm}$ ), $\bigcirc$; glutamate with asparagine (I mM), $\Delta$; glutamate with histidine (I $\mathrm{mM}), \triangle$.

Fig. $5 b$. The $V_{\max }$ for cysteate transport was very low $(0.029 \mu \mathrm{mol} / \mathrm{g}$ dry wt $/ \mathrm{min})$; it was therefore not possible to obtain kinetic data for the inhibition of cysteate transport by glutamate or by aspartate.

Summary of kinetic data for the acidic amino-acid permease of Aspergillus nidulans. The $K_{m}, K_{i}$ and $V_{\text {max. }}$ values calculated for L-glutamate, L-aspartate and L-cysteate transport are summarized in Table 3 . The similarity between the $K_{m}$ and $K_{i}$ values for each amino acid indicates that the three amino acids were taken up by the same system. Although glutamate was transported at the greatest rate, aspartate had the highest affinity for the acidic aminoacid permease. The structure of L-cysteate satisfies the general specificity requirement of the permease $\left(\mathrm{R}^{-} . \mathrm{CH}\left(\mathrm{NH}_{3}^{+}\right) . \mathrm{COO}^{-}\right)$and this amino acid must have bound to the same site as glutamate and aspartate. The extremely low $V_{\max }$ value for uptake of L-cysteate indicates, however, that this uptake may have little physiological significance for nitrogen metabolism. When provided as the sole nitrogen source, L-cysteate does not support germination of Aspergillus nidulans conidia.

\section{DISCUSSION}

In Aspergillus nidulans, active transport systems have been described for purines (Darlington \& Scazzocchio, I967), sulphate (Arst, I968; Bradfield et al. 1970), choline-sulphate (Bellenger, Nissen, Wood \& Segel, 1968) and carbohydrates (Brown \& Romano, 1969; Mark \& Romano, 1971). Three amino-acid permeases have been reported; a phenylalanine permease (which possibly also transports other amino acids) (Sinha, I969), a basic amino acid permease (Cybis \& Weglenski, I969), and a general amino-acid permease (Hackette, Skye, Burton \& Segel, 1970). Evidence has recently been presented (Cook \& Anthony, I973; Anthony \& Cook, 1973) that a permease capable of active transport of methylamine and ammonia is formed during germination of conidia of Aspergillus nidulans. 

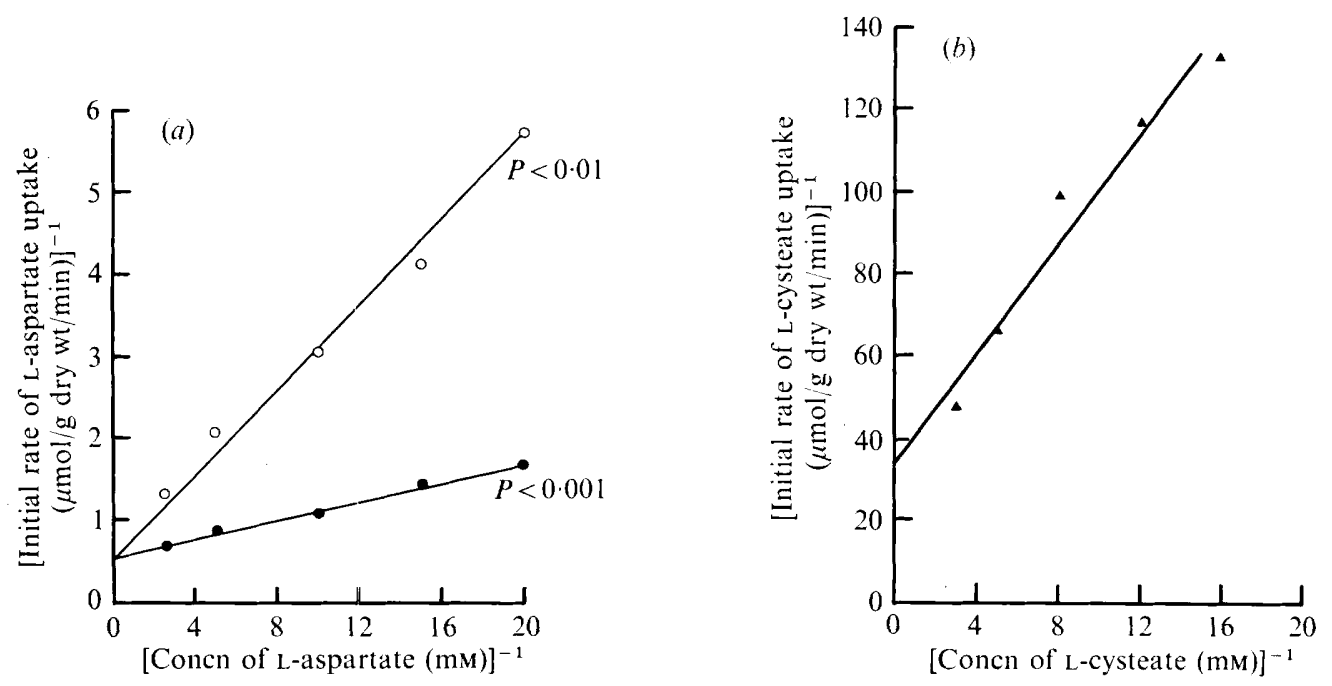

Fig. 5. Kinetics of L-aspartate and L-cysteate transport by germinated conidia of Aspergillus nidulans. Except for the substrate amino acid used, the transport assay system was that described for the assay of glutamate transport. Experimental details were as given for Fig. 3. (a) Transport of L- $\left[\mathrm{U}-{ }^{14} \mathrm{C}\right]$ aspartate. Aspartate alone, $(\bullet)$; aspartate with L-glutamate $(0.5 \mathrm{mM}),(\mathrm{O}) .(b)$ Transport of $L-\left[{ }^{35}\right.$ S $]$ cysteate, $(\mathbf{\Lambda})$.

Table 3. Summary of kinetic data for transport of L-glutamate, L-aspartate and L-cysteate by germinated conidia of Aspergillus nidulans

These kinetic data were calculated from data presented in Fig. 2 to 5.

$\begin{array}{lc}\text { L-Glutamate } & \\ K_{m} \text { for glutamate uptake } & 180 \mu \mathrm{M} \\ K_{i} \text { for glutamate inhibition of aspartate uptake } & 150 \mu_{\mathrm{M}} \\ V_{\max } \text { for glutamate uptake } & 4.35 \mu \mathrm{mol} / \mathrm{g} / \mathrm{min} \\ \text { L-Aspartate } & \\ K_{m} \text { for aspartate uptake } & 100 \mu \mathrm{M} \\ K_{i} \text { for aspartate inhibition of glutamate uptake } & 120 \mu \mathrm{M} \\ V_{\max } \text { for aspartate uptake } & \mathrm{I} \cdot 72 \mu \mathrm{mol} / \mathrm{g} / \mathrm{min} \\ \text { L-Cysteate } & \\ K_{m} \text { for cysteate uptake } & 190 \mu \mathrm{M} \\ K_{i} \text { for cysteate inhibition of glutamate uptake } & 240 \mu \mathrm{M} \\ V_{\max } \text { for cysteate uptake } & 0.03 \mu \mathrm{mol} / \mathrm{g} / \mathrm{min}\end{array}$

The results in this paper indicate that L-glutamate, L-aspartate and L-cysteate were actively transported by an acidic amino-acid permease in germinated conidia of Aspergillus nidulans. This permease had a similar specificity to that of Neurospora crassa (Pall, 1970), but the $K_{m}$ values differed by an order of magnitude ( $K_{m}$ for glutamate transport in $A$. nidulans, I $80 \mu \mathrm{M}$; $K_{m}$ in $N$. crassa, I6 $\mu \mathrm{M}$ ). The permeases of both fungi showed little affinity for neutral or basic amino acids and they were absent from conidia.

The acidic amino-acid permease of Aspergillus nidulans may function to provide the organism with L-glutamate and L-aspartate as nitrogen sources when other sources (such as ammonia) are not available. In support of this hypothesis it has been found that the activity of this permease was high in conidia germinated with glutamate as sole nitrogen source (Robinson et al. I973). 
We thank Professor K. A. Munday for his encouragement in this work and Rank Hovis McDougall (Research) Ltd for financial assistance.

\section{REFERENCES}

Ahmed, K. \& Scholffield, P. G. (1962). Biochemical studies on I-aminocyclopentane carboxylic acid. Canadian Journal of Biochemistry and Physiology 40, I IOI-I I 10.

ANTHONY, C. \& COOK, R. J. (1973). Regulation of methylamine transport during germination of Aspergillus nidulans. Journal of General Microbiology, 77, vii.

ARst, H. N. (1968). Genetic analysis of the first steps of sulphate metabolism in Aspergillus nidulans. Nature, London 219, 268-270.

Bellenger, N., Nissen, P., Wood, T. C. and Segel, I. H. ( I968). Specificity \& control of choline-O-sulphate transport in filamentous fungi. Journal of Bacteriology 96, 1574-1585.

Bradfield, G., Somerfield, P., Meyn, T., Holby, M., Babcock, D., Bradley, D. \& Segel, I. H. (1970). Regulation of sulphate transport in filamentous fungi. Plant Physiology 46, 720-727.

Brown, C. E. \& Romano, A. H. (1969). Evidence against necessary phosphorylation during hexose transport in Aspergillus nidulans. Journal of Bacteriology roo, 1 198-I 203.

COOK, R. J. \& ANTHONY, C. (I973). Active transport of methylamine and ammonia in germinating conidia of Aspergillus nidulans. Journal of General Microbiology, 77, vii.

Cybis, J. \& WeglensKi, P. (1969). Effects of lysine on arginine uptake and metabolism in Aspergillus nidulans. Molecular and General Genetics I04, 282-287.

Darlington, A. J. \& SCAzzocchio, C. (I967). Use of analogues and the substrate-sensitivity of mutants in analysis of purine uptake and breakdown in Aspergillus nidulans. Journal of Bacteriology 93, 937-940.

GaLe, E. F. (197I). 'Don't talk to me about permeability'. The tenth Marjory Stephenson Memorial Lecture. Journal of General Microbiology 68, 1-14.

Hackette, S. L., Skye, G. E., Burton, C. \& Segel, I. H. (1970). Characterisation of an ammonium transport system in filamentous fungi with methylammonium- ${ }^{-14} \mathrm{C}$ as the substrate. Journal of Biological Chemistry 245, 424I-4250.

Hunter, D. R. \& Segel, I. H. (197I). Acidic and basic amino acid transport systems of Penicillium chrysogenum. Archives of Biochemistry and Biophysics 144, 168-183.

Hunter, F. E. \& SchwarTz, L. S. (1967). Valinomycin. In Antibiotics I, pp. 631-635. Edited by D. Gottlieb and P. D. Shaw. New York: Springer and Verlag.

Kaplan, N. O., Ciotti, M. M. \& Stolzenbach, F. E. (1956). Reaction of pyridine nucleotide analogues with dehydrogenases. Journal of Biological Chemistry 221, 833-844.

Mark, C. G. \& Romano, A. H. (1971). Properties of the hexose transport systems of Aspergillus nidulans. Biochimica et biophysica acta 249, $216-226$.

MATHER, K. (1965). Statistical Analysis in Biology, pp. I09-I29. London: Methuen.

MOORE, S. (1963). On the determination of cystine as cysteic acid. Journal of Biological Chemistry 238, 235-237.

Pall, M. L. (1970). Amino acid transport in Neurospora crassa. III. Acidic amino acid transport. Biochimica et biophysica acta $2 \mathrm{II}, 5 \mathrm{I} 3-520$.

Pontecorvo, G., Roper, J. A., Hemmons, L. M., MacDonald, K. D. \& Bufton, A. W. J. (I953). The genetics of Aspergillus nidulans. Advances in Genetics 5, I4I-238.

Robinson, J. H. (1973). Amino acid transport in Aspergillus nidulans. Ph.D. Thesis: University of Southampton.

Robinson, J. H., Anthony, C. \& Drabble, W. T. (197I). Activity and regulation of an acidic amino acid permease of Aspergillus nidulans. Biochemical Journal I24, 75P.

Robinson, J. H., Anthony, C. \& Drabble, W. T. (1973). Regulation of the acidic amino-acid permease of Aspergillus nidulans. Journal of General Microbiology, 79, 65-80.

SinHA, U. (1969). Genetic control of the uptake of amino acids in Aspergillus nidulans. Genetics 62, 495-505. 